\title{
Memory $T$ cells skew toward terminal differentiation in the CD8+ T cell population in patients with acute myeloid leukemia
}

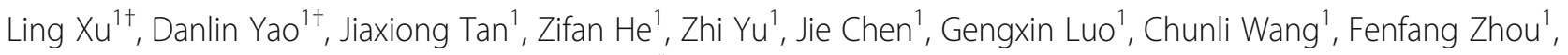
Xianfeng Zha², Shaohua Chen ${ }^{1}$ and Yangqiu Li ${ }^{1 *}$ (D)

\begin{abstract}
Stem cell memory $T\left(T_{S C M}\right)$ and central memory $T\left(T_{C M}\right)$ cells can rapidly differentiate into effector memory $\left(T_{E M}\right)$ and terminal effector $\left(T_{E F}\right) T$ cells, and have the most potential for immunotherapy. In this study, we found that the frequency of $T_{S C M}$ and $T_{C M}$ cells in the CD8+ population dramatically decreased together with increases in $T_{E M}$ and $T_{E F}$ cells, particularly in younger patients with acute myeloid leukemia (AML) $(<60$ years). These alterations persisted in patients who achieved complete remission after chemotherapy. The decrease in $T_{S C M}$ and $T_{C M}$ together with the increase in differentiated $T_{E M}$ and $T_{E F}$ subsets in CD8+ $T$ cells may explain the reduced $T$ cell response and subdued anti-leukemia capacity in AML patients.
\end{abstract}

Keywords: Stem cell memory T cells, Central memory T cells, Effector memory T cells, CD8+ T cells, Acute myeloid leukemia, Bone marrow, Peripheral blood

\section{To the editor}

Clinical applications of immunotherapy for AML lag behind those for solid tumors and lymphocytic leukemia [1-3]. Recently, a new memory $\mathrm{T}$ cell subset, stem cell memory $\mathrm{T}\left(\mathrm{T}_{\mathrm{SCM}}\right)$, which has stem cell-like capacity, has been discovered [4-6]. However, little is known about the role of these cells in AML. In this study, we assessed the distribution of $\mathrm{CD} 4+$ and $\mathrm{CD} 8+\mathrm{T}_{\mathrm{SCM}}$, central memory $\mathrm{T}\left(\mathrm{T}_{\mathrm{CM}}\right), \mathrm{T}$ effector memory $\left(\mathrm{T}_{\mathrm{EM}}\right)$, and $\mathrm{T}$ terminal effector $\left(\mathrm{T}_{\mathrm{EF}}\right)$ cells in peripheral blood $(\mathrm{PB})$ and bone marrow (BM) from patients with AML and those with AML in complete remission (AML-CR) by multicolor flow cytometry. The gating strategy used in this study followed a published protocol [7]. The CD4+ and CD8+ $\mathrm{T}$ cells were divided into four subgroups according to the CCR7 and CD45RO expression pattern: naïve and

\footnotetext{
* Correspondence: yangqiuli@hotmail.com

${ }^{\dagger}$ Ling Xu and Danlin Yao contributed equally to this work.

${ }^{1}$ Department of Hematology, First Affiliated Hospital, Institute of Hematology, School of Medicine; Key Laboratory for Regenerative Medicine of Ministry of Education, Jinan University, No.601 West of Huangpu Avenue, Guangzhou 510632, China

Full list of author information is available at the end of the article
}

$\mathrm{T}_{\mathrm{SCM}}$ cells (CCR7+CD45RO-), $\mathrm{T}_{\mathrm{CM}}$ cells (CCR7 +CD45RO+), $\mathrm{T}_{\mathrm{EM}}$ cells (CCR7-CD45RO+), and $\mathrm{T}_{\mathrm{EF}}$ cells (CCR7-CD45RO-). The $\mathrm{T}_{\mathrm{SCM}}$ population was defined by double positive CD95 and CD28 expression.

The percentages of the $\mathrm{T}_{\mathrm{SCM}}, \mathrm{T}_{\mathrm{CM}}, \mathrm{T}_{\mathrm{EM}}$, and $\mathrm{T}_{\mathrm{EF}}$ cells in the $\mathrm{CD} 4+$ and $\mathrm{CD} 8+$ populations were analyzed in 20 cases with AML (17 cases in newly diagnosed and 3 cases with AML relapse) (Fig. 1a, d) [8, 9]. The CD8+ $\mathrm{T}_{\mathrm{SCM}}$ and $\mathrm{CD} 8+\mathrm{T}_{\mathrm{CM}}$ cells significantly decreased in the PB of these patients (Fig. 1e, g), whereas there was no significant change in the CD4+ population (Fig. 1b, g). Thus, the changes in the memory $\mathrm{T}$ cell subsets appeared to mainly involve CD8+ $\mathrm{T}$ cells. The shift from $\mathrm{T}_{\mathrm{SCM}}$ and $\mathrm{T}_{\mathrm{CM}}$ cells to a higher ratio of differentiated $\mathrm{T}_{\mathrm{EM}}$ and $\mathrm{T}_{\mathrm{EF}}$ cells is thought to be due to the constant exposure of $\mathrm{T}$ cells to AML cells and the leukemia environment, leading to $\mathrm{T}$ cell exhaustion and/or dysfunction [3].

To study the influence of the tumor microenvironment on the memory $\mathrm{T}$ cell distribution and function in leukemia patients, we collected seven pairs of $\mathrm{PB}$ and BM samples from AML patients at the time of diagnosis 


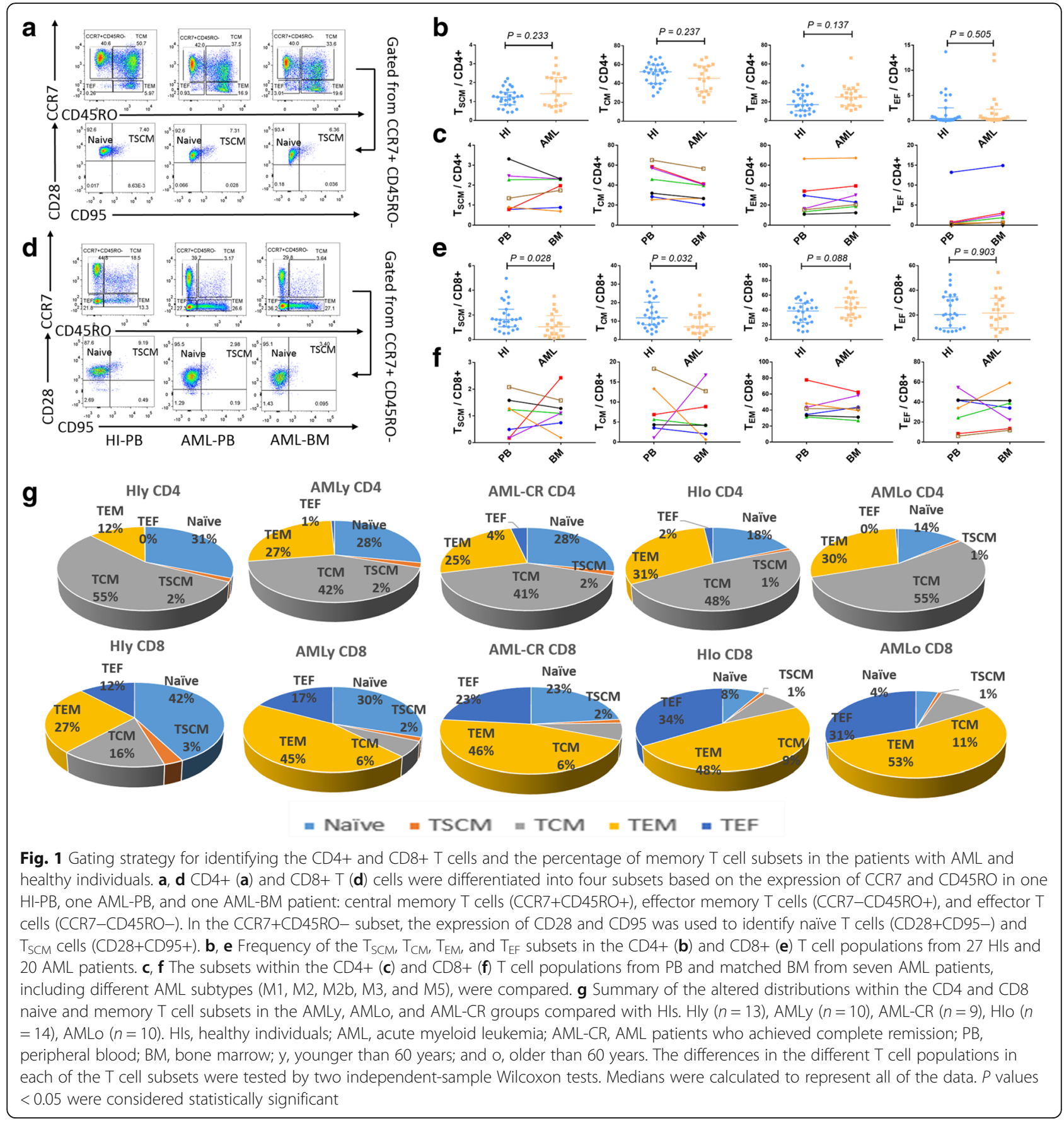

and compared the distributions of memory $\mathrm{T}$ cell subsets. The differences in each subset appeared to vary widely (Fig. 1c, f). A low percentage of CD4+ $T_{C M}$ cells and a corresponding high percentage of CD4+ $\mathrm{T}_{\mathrm{EM}}$ and $\mathrm{T}_{\mathrm{EF}}$ cells were observed in the $\mathrm{BM}$ compared with $\mathrm{PB}$ (Fig. 1c). In the $\mathrm{CD} 8+$ population, the changes appeared to be specific to each individual, and lower $\mathrm{CD} 8+\mathrm{T}_{\mathrm{SCM}}$ and $\mathrm{CD} 8+\mathrm{T}_{\mathrm{CM}}$ percentages were observed in the $\mathrm{BM}$ in half of the patients, whereas there were high percentages of $\mathrm{CD} 8+\mathrm{T}_{\mathrm{SCM}}$ and $\mathrm{CD} 8+\mathrm{T}_{\mathrm{CM}}$ cells in the $\mathrm{BM}$ compared with $\mathrm{PB}$ in the remaining samples. It has been reported that $\mathrm{T}$ cells in normal BM mainly possess a memory phenotype, particularly for $\mathrm{CD} 8+\mathrm{T}_{\mathrm{CM}}$ cells [10], suggesting that alterations in the leukemic BM niche in different AML individuals and AML subtypes may have different impact on $\mathrm{T}_{\mathrm{CM}}$ homing.

Next, we compared the distribution of memory T cells in AML patients younger (AMLy) and older (AMLo) than 60 years [11]. Unlike healthy individuals (HIs), the memory $\mathrm{T}$ cell subset distribution in the AMLy cohort 


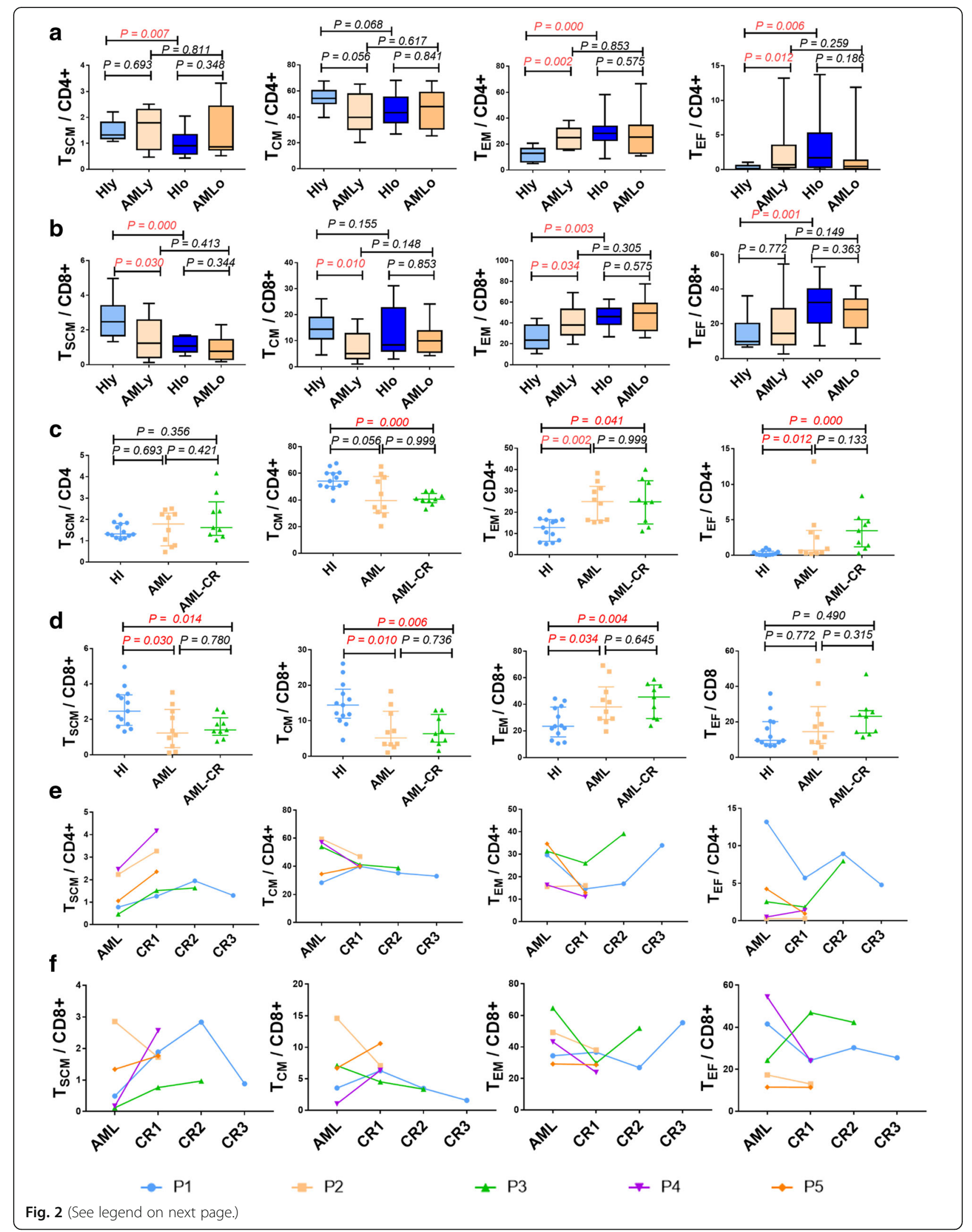


(See figure on previous page.)

Fig. 2 Memory T cell subset distribution in CD4+ and CD8+ T cells in patients younger or older than 60 years with AML and AML-CR. a, b TSCM, $T_{C M}, T_{E M}$, and $T_{E F}$ subsets within the CD4+ (a) and CD8+ (b) populations in the Hly, AMLy, Hlo, and AMLo groups. Hly $(n=13), A M L y(n=10), H l O$ $(n=14)$, and AMLo $(n=10)$. c, d: Frequency of $\mathrm{T}_{\mathrm{SCM}}, \mathrm{T}_{\mathrm{CM}}, \mathrm{T}_{\mathrm{EM}}$, and $\mathrm{T}_{\mathrm{EF}}$ cells within the CD4+ (c) and CD8+ (d) T cell populations in age matched HI, AML and AML-CR cohorts. HIs $(n=13), \operatorname{AML}(n=10)$, and AML-CR $(n=10)$. e, $\mathbf{f}$ Five AML patients were dynamically assayed for the $\mathrm{T}_{\mathrm{SCM}}, \mathrm{T}_{\mathrm{CM}}$, $T_{E M}$, and $T_{E F}$ subsets in the CD4+ (e) and CD8+ (f) T cell populations at different time points. AML-CR, AML patients who achieved complete remission; P, patient; CR1, 2, 3, indicate different time points at which the patient achieved CR

was strikingly different than that in younger HIs (HIy) and tended to have a similar distribution pattern as that detected in the HIo and AMLo groups with a more obvious difference in the $\mathrm{CD} 8+$ population (Figs. 1g and $2 \mathrm{a}, \mathrm{b})$. These findings indicate that the leukemia microenvironment might drive $\mathrm{T}$ cell differentiation in AMLy. Whether such a skewed $\mathrm{T}$ cell distribution in AMLy truly represents $\mathrm{T}$ cell senescence remains an open question [8]; however, T cells in AMLo patients may not be able to further differentiate due to inherent $\mathrm{T}$ cell senescence, which may be an immune factor underlying the inferior prognosis of AMLo patients. Together, these data may suggest that $\mathrm{T}$ cell exhaustion and senescence are involved in $\mathrm{T}$ cell immune impairment, leading to an inefficient anti-tumor response.

We next compared differences in the distribution of memory $\mathrm{T}$ cell subsets between the AMLy, AML-CR, and HIy groups. A persistent, skewed memory T cell distribution was demonstrated for AML patients who achieved CR after chemotherapy (Fig. 2c, d). CD4+ and $\mathrm{CD} 8+\mathrm{T}_{\mathrm{SCM}}$ cells were predominantly increased at different time points after $\mathrm{CR}$, while the change in other memory $\mathrm{T}$ cell subsets was relatively different (Fig. 2e, f). Overall, with the exception of incomplete recovery of the $\mathrm{T}_{\mathrm{SCM}}$ cells, the reduction in $\mathrm{T}_{\mathrm{CM}}$ cells and corresponding excessive accumulation of $\mathrm{T}_{\mathrm{EM}}$ and $\mathrm{T}_{\mathrm{EF}}$ cells were more evident in AML patients with CR (Fig. 1g), which may be related to the immune suppression of chemotherapy.

\section{Abbreviations}

AML: Acute myeloid leukemia; BM: Bone marrow; CML: Chronic myeloid leukemia; CR: Complete remission; HSCT: Hematopoietic stem cell transplantation; PB: Peripheral blood; PBMCs: Peripheral blood mononuclear cells; TСм: Central memory T cells; $T_{E F}$ : Terminal effector T cells; $T_{\text {EM }}$ : Effector memory $T$ cells; $T_{\text {scm: }}$ : Stem cell memory $T$ cells

\section{Acknowledgements}

We want to thank the flow facility of the Biological Translational Research Institute of Jinan University as well as Yanqiong Jia, a research assistant from the Translational Research Institute of Jinan University. We also would like to thank the volunteers who donated blood for this project.

\section{Funding}

This study was supported by grants from the National Natural Science Foundation of China (Nos. 91642111, 81770152, and 81570143), the Guangdong Provincial Basic Research Program (No. 2015B020227003), the Guangdong Provincial Applied Science and Technology Research \& Development Program (No. 2016B020237006), the Guangzhou Science and Technology Project (Nos. 201510010211, 201807010004, and 201803040017), and Special Funds for the Cultivation of Guangdong
College Students' Scientific and Technological Innovation (No. pdjh2017b0065).

\section{Availability of data and materials}

The datasets used and/or analyzed during the current study are available from the corresponding author on reasonable request.

\section{Authors' contributions}

YQL contributed to the concept development and study design. LX coordinated the study. LX, DLY, JXT, ZFH, SHL, XFZ, and SHC performed the laboratory studies. ZY, JC, GXL, CLW, and FFZ collected the clinical data. DLY contributed to figure preparation. YQL, $X \mathrm{~L}$, and $\mathrm{DLY}$ drafted the manuscript. All authors read and approved the final manuscript.

\section{Ethics approval and consent to participate}

This study was approved by the ethics committee of The First Affiliated Hospital of Jinan University.

\section{Consent for publication}

Not applicable.

\section{Competing interests}

The authors declare that they have no competing interests.

\section{Publisher's Note}

Springer Nature remains neutral with regard to jurisdictional claims in published maps and institutional affiliations.

\section{Author details}

'Department of Hematology, First Affiliated Hospital, Institute of Hematology, School of Medicine; Key Laboratory for Regenerative Medicine of Ministry of Education, Jinan University, No.601 West of Huangpu Avenue, Guangzhou 510632, China. ${ }^{2}$ Department of clinical laboratory, First Affiliated Hospital, Jinan University, Guangzhou 510632, China.

Received: 12 March 2018 Accepted: 29 June 2018

Published online: 09 July 2018

\section{References}

1. Lichtenegger FS, Krupka C, Haubner S, Kohnke T, Subklewe M. Recent developments in immunotherapy of acute myeloid leukemia. J Hematol Oncol. 2017;10(1):142

2. Li Y, Yin Q, Yang L, Chen S, Geng S, Wu X, et al. Reduced levels of recent thymic emigrants in acute myeloid leukemia patients. Cancer Immunol Immunother. 2009;58(7):1047-55.

3. Tan J, Chen S, Lu Y, Yao D, Xu L, Zhang Y, et al. Higher PD-1 expression concurrent with exhausted CD8+ T cells in patients with de novo acute myeloid leukemia. Chin J Cancer Res. 2017:29(5):463-70.

4. Zhang Y, Joe G, Hexner E, Zhu J, Emerson SG. Host-reactive CD8+ memory stem cells in graft-versus-host disease. Nat Med. 2005;11(12):1299-305.

5. Gattinoni L, Lugli E, Ji Y, Pos Z, Paulos CM, Quigley MF, et al. A human memory T cell subset with stem cell-like properties. Nat Med. 2011; 17(10):1290-7.

6. Xu L, Zhang $Y$, Luo G, Li Y. The roles of stem cell memory $T$ cells in hematological malignancies. J Hematol Oncol. 2015;8:113.

7. Lugli E, Gattinoni L, Roberto A, Mavilio D, Price DA, Restifo NP, et al. Identification, isolation and in vitro expansion of human and nonhuman primate T stem cell memory cells. Nat Protoc. 2013;8(1):33-42.

8. Saule P, Trauet J, Dutriez V, Lekeux V, Dessaint JP, Labalette M. Accumulation of memory $T$ cells from childhood to old age: central and 
effector memory cells in CD4(+) versus effector memory and terminally differentiated memory cells in CD8(+) compartment. Mech Ageing Dev. 2006;127(3):274-81.

9. Yao DL, Xu L, Tan JX, Zhang YK, Lu S, Li MD, et al. Re-balance of memory $T$ cell subsets in peripheral blood from patients with CML after TKI treatment. Oncotarget. 2017;8(47):81852-9.

10. Mazo IB, Honczarenko M, Leung H, Cavanagh LL, Bonasio R, Weninger W, et al. Bone marrow is a major reservoir and site of recruitment for central memory CD8+ T cells. Immunity. 2005;22(2):259-70.

11. O'Donnell MR, Tallman MS, Abboud CN, Altman JK, Appelbaum FR, Arber DA, et al. Acute myeloid leukemia, version 3.2017, NCCN clinical practice guidelines in oncology. J Natl Compr Cancer Netw. 2017;15:926-57.

Ready to submit your research? Choose BMC and benefit from:

- fast, convenient online submission

- thorough peer review by experienced researchers in your field

- rapid publication on acceptance

- support for research data, including large and complex data types

- gold Open Access which fosters wider collaboration and increased citations

- maximum visibility for your research: over $100 \mathrm{M}$ website views per year 